\title{
COMPOSITION OF AUSTRALIAN SWEETENED CONDENSED MILK.
}

By E. HOLL MILLER.

(Read at the Meeting, December 6, 1911.)

The following two tables give the composition of samples of five different brands of sweetened condensed milk purchased in Victoria, and six purchased in New South Wales.

These figures are of some interest, as all the milks were manufactured in Australia.

TABLE I.

Purchased in Victoria.

\begin{tabular}{|c|c|c|c|c|c|c|c|c|}
\hline & \multirow{2}{*}{$\begin{array}{l}\text { Brand } \\
\text { No. } 1 .\end{array}$} & \multirow{2}{*}{$\begin{array}{l}\text { Brand } \\
\text { No. } 2 .\end{array}$} & \multirow{2}{*}{$\begin{array}{l}\text { Brand } \\
\text { No. } 3 .\end{array}$} & \multicolumn{2}{|c|}{ Brand No. 4.} & \multicolumn{3}{|c|}{ Brand No. 5.} \\
\hline & & & & Sample $a$. & Sample $b$. & Sample $a$. & Sample $b$ & Sample $c$. \\
\hline Total solids & $72 \cdot 18$ & $72 \cdot 96$ & $73 \cdot 740$ & $76 \cdot 80$ & $76 \cdot 24$ & $75 \cdot 00$ & 74.99 & $74 \cdot 74$ \\
\hline Fat $\quad \ldots$ & $10 \cdot 03$ & $11 \cdot 41$ & $10 \cdot 800$ & $10 \cdot 50$ & $10 \cdot 63$ & $10 \cdot 11$ & $10 \cdot 27$ & $9 \cdot 61$ \\
\hline Ash $\quad \ldots$ & 1.91 & 1.90 & 1.870 & $2 \cdot 04$ & $2 \cdot 01$ & 1.93 & $1 \cdot 90$ & $1 \cdot 94$ \\
\hline Solids-not-fat $\ldots$ & $62 \cdot 15$ & $61 \cdot 55$ & $61 \cdot 940$ & $66 \cdot 30$ & $65 \cdot 61$ & $64 \cdot 89$ & $64 \cdot 72$ & $65 \cdot 13$ \\
\hline Protein $(\mathrm{N} \times 6.38)$ & $9 \cdot 68$ & $9 \cdot 20$ & $9 \cdot 300$ & $9 \cdot 69$ & $10 \cdot 12$ & $9 \cdot 69$ & $9 \cdot 00$ & $9 \cdot 05$ \\
\hline Total sugars $\quad .$. & $50 \cdot 56$ & $50 \cdot 45$ & $50 \cdot 700$ & $54 \cdot 59$ & $53 \cdot 48$ & $53 \cdot 27$ & $53 \cdot 82$ & $54 \cdot 14$ \\
\hline Chlorine & $0 \cdot 19$ & $0 \cdot 18$ & $0 \cdot 188$ & $0 \cdot 18$ & $0 \cdot 24$ & 0.23 & 0.22 & 0.23 \\
\hline Acidity ... & $43 \cdot 8^{\circ}$ & $51^{\circ}$ & $46 \cdot 9^{\circ}$ & $48 \cdot 6^{\circ}$ & $49 \cdot 4^{\circ}$ & $46 \cdot 5^{\circ}$ & $45 \cdot 5^{\circ}$ & $45 \cdot 6^{\circ}$ \\
\hline
\end{tabular}

TABLE II.

Purchased in New South Wales.

\begin{tabular}{|c|c|c|c|c|c|c|}
\hline & $\begin{array}{l}\text { Brand } \\
\text { No. } 1 .\end{array}$ & $\begin{array}{l}\text { Brand } \\
\text { No. } 2 .\end{array}$ & $\begin{array}{l}\text { Brand } \\
\text { No. } 3 .\end{array}$ & $\begin{array}{l}\text { Brand } \\
\text { No. } 4 .\end{array}$ & $\begin{array}{l}\text { Brand } \\
\text { No. } 5 .\end{array}$ & $\begin{array}{l}\text { Brand } \\
\text { No. } 6 .\end{array}$ \\
\hline Total solids & $75 \cdot 87$ & $67 \cdot 53$ & $76 \cdot 14$ & $74 \cdot 77$ & $71 \cdot 38$ & $75 \cdot 87$ \\
\hline Fat ... $\quad .$. & $10 \cdot 68$ & $9 \cdot 41$ & $9 \cdot 28$ & $9 \cdot 81$ & $9 \cdot 93$ & $9 \cdot 05$ \\
\hline Ash ... $\quad \ldots$ & $2 \cdot 10$ & $1 \cdot 82$ & $2 \cdot 11$ & 1.82 & $1 \cdot 84$ & $2 \cdot 10$ \\
\hline Solids-not-fat $\quad \ldots$ & $65 \cdot 19$ & $58 \cdot 12$ & $66 \cdot 86$ & $64 \cdot 96$ & $61 \cdot 45$ & $66 \cdot 82$ \\
\hline Protein $(\mathrm{N} \times 6 \cdot 38) \ldots$ & $10 \cdot 25$ & $9 \cdot 14$ & $9 \cdot 84$ & $8 \cdot 95$ & $9 \cdot 39$ & $9 \cdot 10$ \\
\hline Total sugars $\quad \ldots$ & $52 \cdot 84$ & $47 \cdot 16$ & $59 \cdot 91$ & $54 \cdot 19$ & $50 \cdot 22$ & $55 \cdot 62$ \\
\hline Chlorine $\quad \ldots$ & 0.36 & 0.20 & $0 \cdot 21$ & $0 \cdot 19$ & $0 \cdot 19$ & $0 \cdot 24$ \\
\hline Acidity & $51^{\circ}$ & $56 \cdot 8^{\circ}$ & $51 \cdot 84^{\circ}$ & $44 \cdot 64^{\circ}$ & $50 \cdot 05^{\circ}$ & $49 \cdot 75^{\circ}$ \\
\hline
\end{tabular}

For analysis the whole of the contents of the tin were turned out into a basin and thoroughly mixed, and the portions required were taken from the mixed sample. 
The fat was estimated by Richmond's modification of the Rose-Gottleib method. Other constituents were estimated in the usual manner.

Tyrosin was detected in all the above samples with the exception of Nos. 1 and 3 , Table $\mathrm{I}$.

I have found that tyrosin makes its appearance in sweetened condensed milk between the end of the third and fourth month after manufacture. Samples six months old show distinct crystalline tufts of tyrosin, which can generally be detected on the first slide prepared, when examined under the microscope with a one-sixth inch objective.

Samples twelve months old show fairly large round crystalline feathery tufts. These tufts of crystals all approximate to the same size in the same tin of milk, and the size and number of them form a fairly good criterion of the age of the sample.

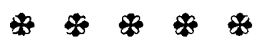

